地質学雑誌 第 113 巻 第 7 号 $353-365$ ページ，2007 年 7 月

Jour. Geol. Soc. Japan, Vol. 113, No. 7, p. 353-365, July 2007

\title{
紀伊半島中央部，中期中新世宮滝岩脈：火道内でのマグマ・ミングリングと その意義
}

The Middle Miocene Miyataki dike, central Kii Peninsula, southwest Japan: magma mingling observed in dike conduit and its implications

\section{和田穣隆 $*$ 藤田千夏 ${ }^{* \dagger}$ 新正裕尚**}

Yutaka Wada*, Chinatsu Fujita ${ }^{* \dagger}$, and Hironao Shinjoe **

2006 年 5 月 8 日受付.

2007 年 1 月 23 日受理.

奈良教育大学地学教室

Department of Earth Sciences, Nara University of Education, Takabatake, Nara 630-8528, Japan.

** 東京経済大学

Tokyo Keizai University, 1-7-34, Minami-Cho, Kokubunji, 185-8502, Japan

, 現所属: 平群町立平群南小学校

Present address; Heguri Minami Elementary School, Tsubai 820, Heguri-Cho, Nara 6360911, Japan

Corresponding author: Y. Wada, ywada@nara-edu.ac.jp

\section{Abstract}

We reexamined the Miocene Miyataki dike exposed at central Kii Peninsula, southwest Japan to infer the emplacement process of the dike. Although the dike has been regarded as of pyroclastic origin, our detailed field and petrographical investigations reveal that the Miyataki dike is composed of andesite mingled with rhyolite. In addition, granite enclaves also occur both in andesite and rhyolite, and those in rhyolite are often mantled by andesite. Shapes of rhyolite, andesite and granite enclaves are irregular and amoeboidal, indicative of ductile deformation during dike emplacement. These evidences show that andesite and rhyolite magmas and granite body could mingle with one another before dike emplacement, and that after the interaction, mingled magma rose to form the Miyataki dike. Whole rock compositions also support this mingling model for the Miyataki dike. Therefore, the facies and structures observed in the Miyataki dike are considered to be formed by a physical mingling processes in dike conduit.

Key words: Miyataki dike, Miocene volcanism, Kii Peninsula, southwest Japan, magma mingling

\section{は じめに}

紀伊半島中央部，奈良県吉野町宮滝付近には発泡の見られ る不定形の火山岩片と堆積岩片を多量に含んだ岩脈（以後, 宮滝岩脈と呼ぶ）が知られている (Fig. 1)。この岩体は日本 の地質「近畿地方」編集委員会（1987 の図 2.57）がその位 置を最初に記載した後, 大和大峯研究グループ (1994) が東 西性の長石と石英の斑晶が顕著な流紋岩質火砕岩岩脈として 報告したものであるが，産状の詳細は記載されていない，一 方，和田ほか（2000）は宮滝岩脈の東方約 $1.5 \mathrm{~km}$ にある吉 野町整尾の吉野川河床においてデイサイト岩脈（D21）を記 載し，走向および異質岩片を多量に含む岩相が大和大峯研究 グループ（1994）の記した宮滝岩脈のそれと類似することか ら両者を同一の岩脈と見なしたが, 宮滝露頭においては岩脈 中に本質岩片として発泡したものと流動変形したものが含ま れ，また多量の異質岩片も含まれていることを述べた。 しか し，樫尾露頭では破砕結晶を含むものの，火砕岩ではなく火 山岩（デイサイト）と記載しており，多少の混乱がある。一 般に岩脈の岩相は火山岩相から火砕岩相へ漸移することもあ るが，宮滝岩脈については，そのように漸移している岩相か
らなるものなのか否かがこれまでの記載を見る限り明らかで なかった，そこで我々は宮滝岩脈の産状を再検討した結果， 岩脈は流紋岩と安山岩が互いに包有し合うミングリング (mingling) 構造を持つものであることがわかつた．本論文 では宮滝岩脈の産状について報告する.

ところでマグマ・ミングリング (magma mingling) とは 組成・温度・結晶度などの異なる 2 種類（あるいはそれ以 上）のマグマの混合過程において，不均質な状態・産状ある いはそれらを生じる現象を指す（Shelley, 1992; Hibbard, 1995)。したがって，不均質であることが肉眼で容易に認識 できる場合，例えば深成岩体中の包有物が不規則形状を示す 様子 (Wiebe, 1991) や複合溶岩における 2 種類の火山岩が 不規則に混じり合った様子（川畑・周藤，2000）のように， その火成岩の構造・組織に対してミングリングという語がよ く用いられる，一方で，英語での本来の意味に基づき異なる マグマ間の現象・産物にのみ適用されるばかりでなく, 例え ばマグマと末固結堆積物の不均質混合現象とその産物に対し ても用いられる (例えば, Zimanowski and Büttner, 2002; 和 田・三浦, 2005)。本稿で用いるミングリングは前者の意味 である. 


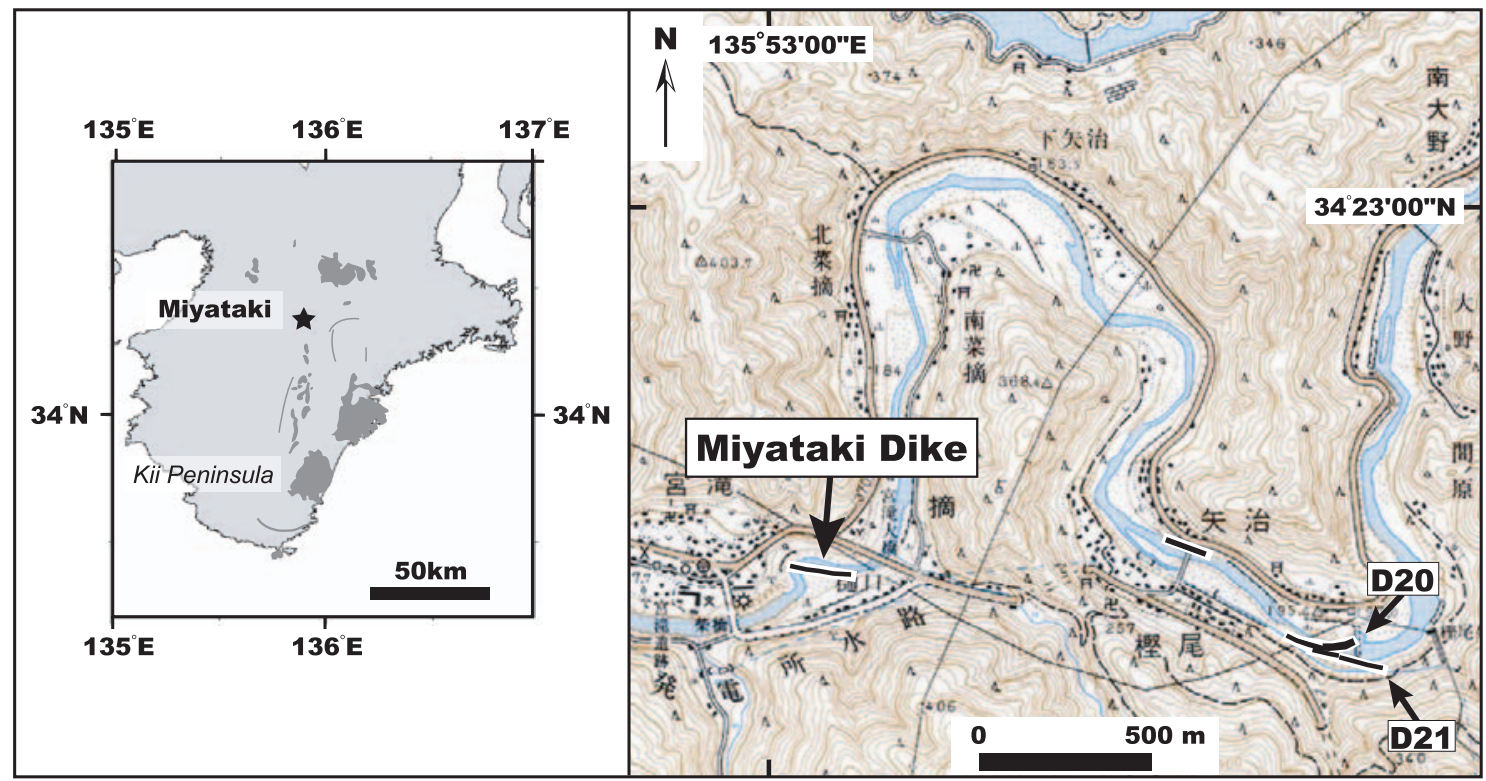

Fig. 1. Index maps of the Miyataki dike (1:25,000 geographical map "Atarashi"). Locations of the basalt-rhyolite composite dike (D20) and the dacite dike (D21) are based on Wada et al. (2000). Darker parts in the left inset show Miocene igneous bodies in Kii Peninsula.

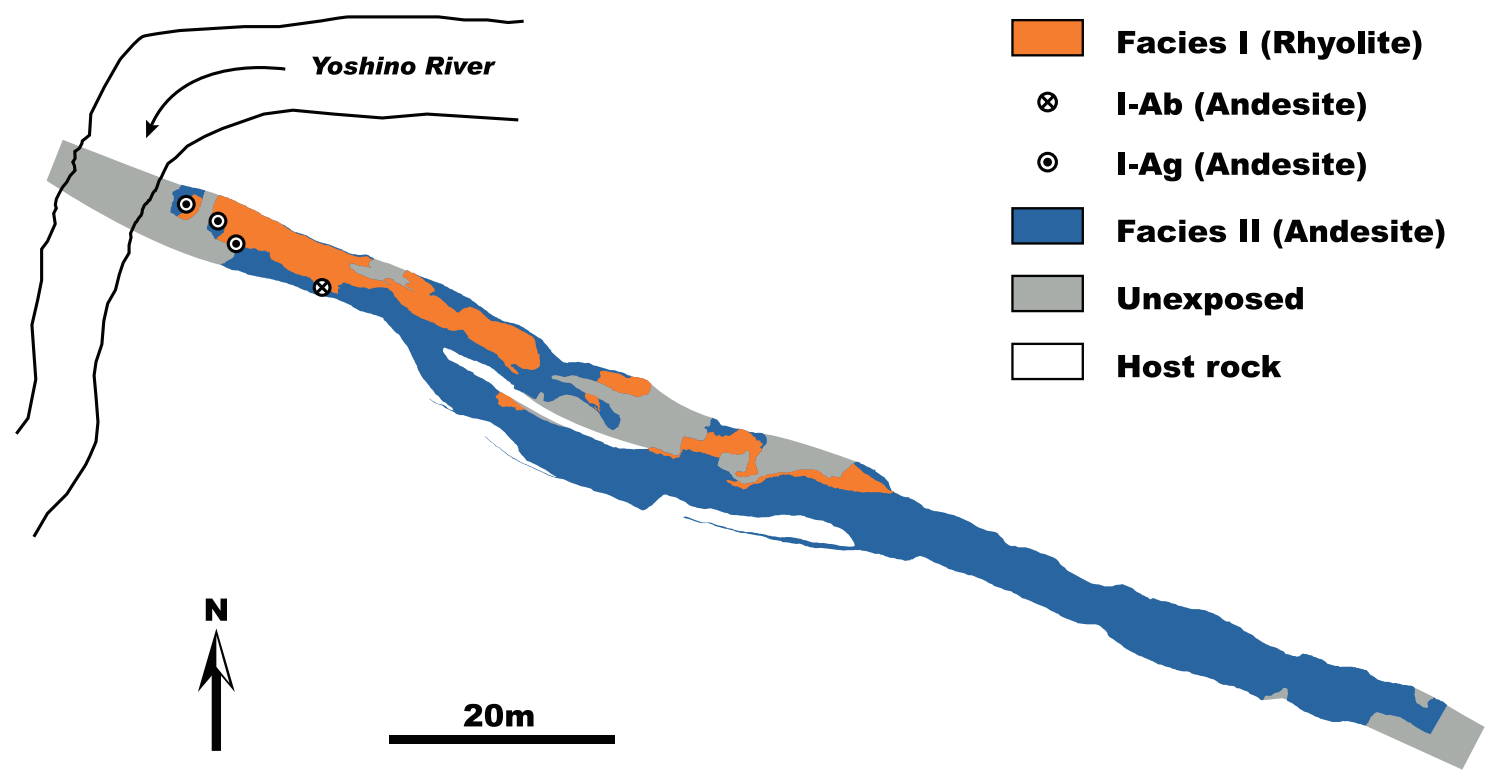

Fig. 2. Facies distribution within the Miyataki dike.

宮滝岩脈の形成年代は明らかでないものの中期中新世と見 なされている（大和大峯研究グループ, 1994, 2005)。したが って, 紀伊半島に分布する中新世火成岩体である熊野酸性火 成岩類や大峯花崗岩質岩との成因的関連についても考慮する 必要がある。宮滝岩脈が分布する地域の南方には大峯花崗岩 質岩に相当する中期中新世の花崗岩質岩体の伏在が推定され ている (新正ほか, 2003)。この推定は宮滝地域の東方の樫尾 地域に露出する複合岩脈（和田ほか, 2000 の D20）中に含ま れる花崗岩包有物の産状・全岩化学組成・ジルコン $\mathrm{U}-\mathrm{Pb}$ 年 代に基づいている. 今回, 宮滝岩脈中にも樫尾の複合岩脈中
に見られるものと同様な産状の花崗岩包有物が見出され，そ れは宮滝南方に伏在すると考えられる岩体を含めた周辺の中 新世花崗岩体との成因的関連を強く示唆する. この包有物の 産状についても併せて報告する.

\section{宮 滝 岩 脈}

宮滝岩脈は紀伊半島中央部，奈良県吉野町宮滝付近の吉野 川左岸の河床に約 $150 \mathrm{~m}$ にわたつて露出する (Fig. 1)。岩 脈の母岩は砂岩泥岩互層で, 四万十帯の槙尾コンプレックス とされる（大和大峯研究グループ, 2005)。剪断変形面が平行 

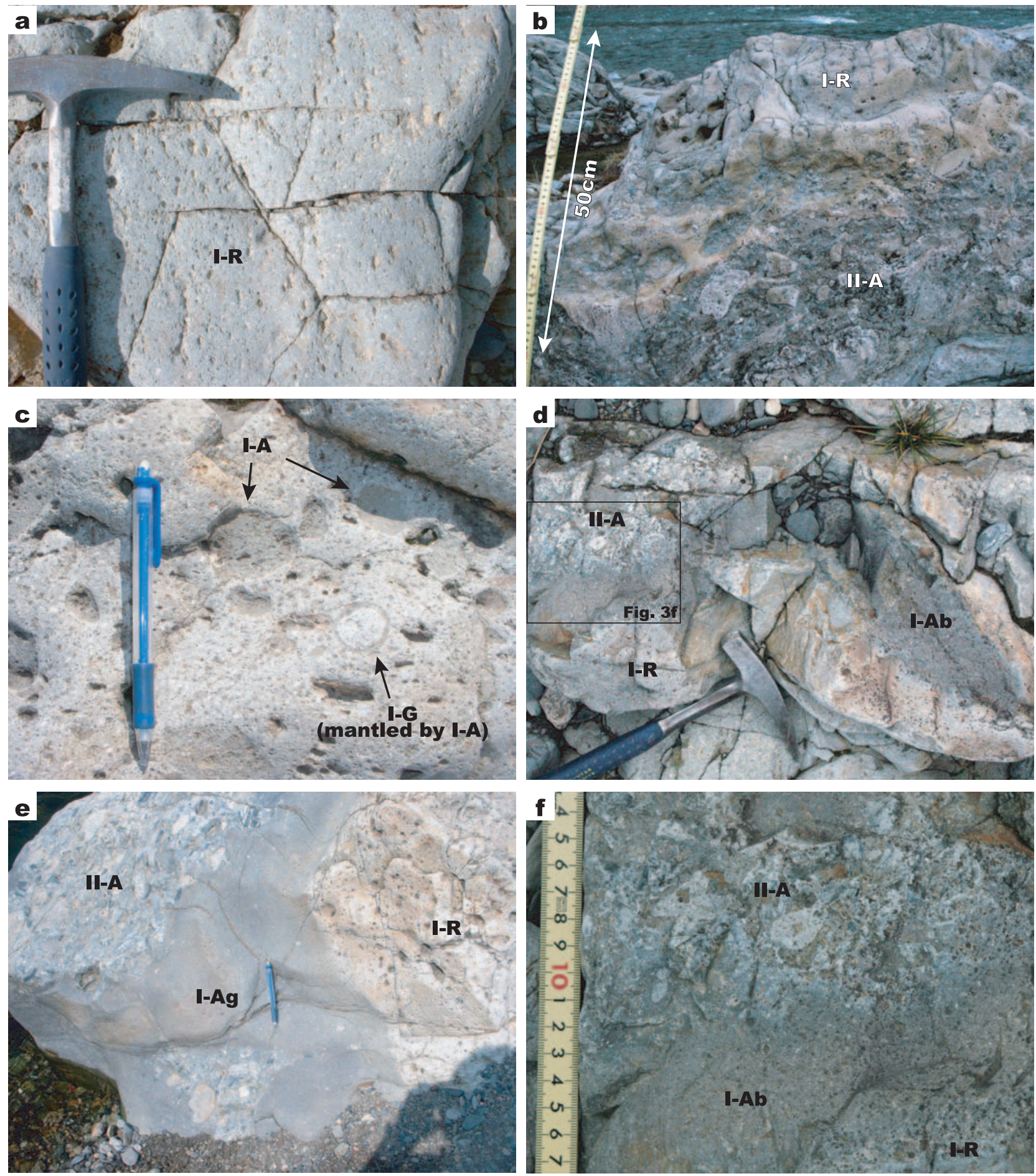

Fig. 3. Field occurrences of the Facies I of Miyataki dike. (a) I-R (rhyolite). Many pumices up to a several centimeters are observed. (b) Irregular boundary zone of I-R and II-A (andesite). (c) I-A (andesite) and I-G (granite) enclaves mantled by I-A in I-R. Both are rounded indicating ductile deformation. (d) I-Ab (andesite) is localized at the margin of Facies I, and its shape is lensoidal. (e) I-Ag (andesite) is also localized at the margin of the Facies I. (f) Close-up of the irregular boundary between I-Ab and II-A.

によく発達し、レンズ状泥岩が砂岩に挟在している場合もあ る. 剪断変形面の走向・傾斜は $\mathrm{N} 20^{\circ} \mathrm{W}, 90^{\circ}$ である。宮滝 岩脈周辺には, 東方約 $1 \sim 1.5 \mathrm{~km}$ の吉野町樫尾付近に玄武 岩と流紋岩からなる複合岩脈・粗面安山岩岩脈・デイサイト 岩脈が分布し，いずれも走向はほぼ東西に近い（Fig. 1; 和田
ほか, 2000)。また北方の菜摘付近にも東西走向の岩脈の報告 があるが (大和大峯研究グループ, 1994), 産状についての詳 細は明らかでない.

宮滝岩脈全体の走向・傾斜は $\mathrm{N} 70 \sim 80^{\circ} \mathrm{W}$, 垂直で, 露 頭面上での岩脈の最大幅は $10 \mathrm{~m}$ から $2 \mathrm{~m}$ まで変動する 

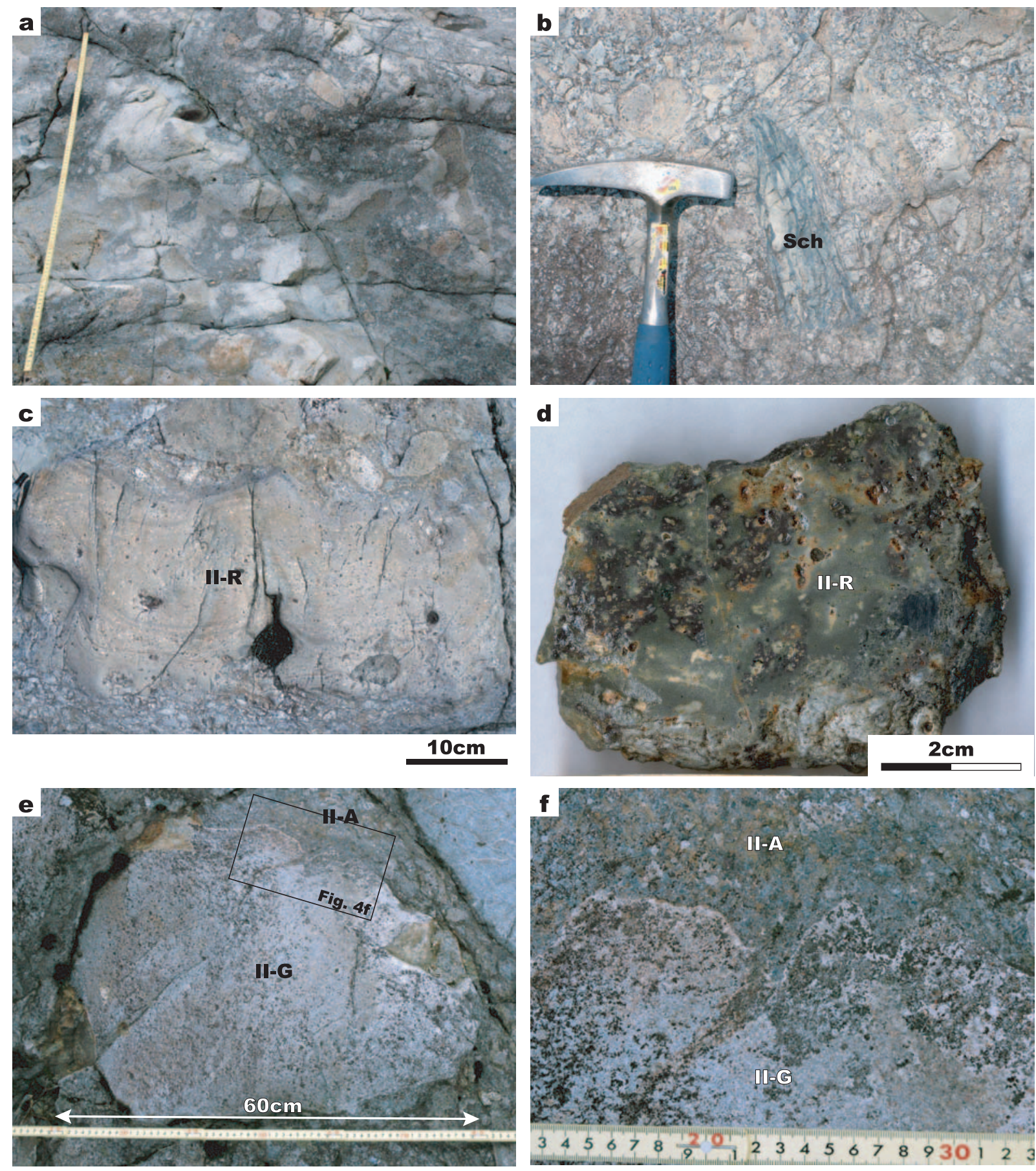

Fig. 4. Field occurrences of the Facies II of Miyataki dike. (a) II -A (andesite) includes many irregularly shaped rhyolite and granite enclaves with host rock fragments. (b) A metamorphic schist fragment showing a blocky shape. (c) A II-R (rhyolite) enclave indicates flow bands parallel to the margin, and irregular shape. (d) This II-R enclave is amoeboidal shaped. (e) The largest II-G (granite) enclave exposed. (f) Closeup view of the II -G enclave, showing the wavy margin.

(Fig. 2). 露頭の中央部からやや西寄りでは分岐して 2 枚の 岩脈が並走する．南側の母岩との境界では主岩脈から西に向 かって尻尾状の分岐岩脈が 3 枚派生している. 分岐岩脈の最 大幅はいずれも約 $0.5 \mathrm{~m}$ で, 最長のものは主岩脈にほぼ平行 に約 $10 \mathrm{~m}$ 貫入する. 最も東側の分岐岩脈の走向・傾斜は $\mathrm{N} 64^{\circ} \mathrm{W}, 87^{\circ} \mathrm{N}$ である. 北側の境界では母岩中に最大幅数 $\mathrm{cm}$ の分岐岩脈が長さ約 $15 \mathrm{~cm}$ 貫入するの夕である.
宮滝岩脈では流紋岩からなる岩相 I 全体が安山岩からなる 岩相 IIに包有されるミングリング構造を持つ。また，岩相 I の流紋岩には安山岩・花崗岩が包有される一方, 岩相 II の安 山岩には流紋岩・花崗岩が包有される，これらの包含関係は 肉眼スケールでも顕微鏡スケールでも確認できる. 以下，岩 相 I・II の野外での産状と岩石組織について述べる. 


\section{1. 野外での産状}

(1) 岩相 I

岩相 I は流紋岩（I-R）を主体として長さ約 $40 \mathrm{~m}$ ，幅約 2 $\mathrm{m}$ の広がりを持つ。全体の形状は走向方向に伸びている (Fig. 2). I-R の中に安山岩（I-A）・花崗岩（I-G）が包有物 として散在する．また I-R と岩相 II との境界に沿つて局所的 に黒色安山岩 (I-Ab), 灰色安山岩 (I-Ag) が挟在する.

[I-R 流紋岩］Ｉ-R は岩脈露頭の比較的西寄りに位置し，一 部は母岩と直接接するものの, 大部分は岩相 Iに接しており 巨大な包有物と見なすことができる. 全体的に数\%程度発泡 し軽石も認められる (Fig. 3.a). 中心部ほど気泡径が大き <, 最大 $7 \mathrm{~cm}$ に達する. 一方, 母岩や岩相 II との境界に近 い縁辺部では緻密で発泡はほとんどなく流理構造が発達す る. I-R の縁辺部では複雑に入り組んだ境界面を形成するこ とが多く，一部には岩相 II を包有しミングリングしている (Fig. 3.b)。局所的には黒色安山岩（I-Ab）や灰色安山岩（I$\mathrm{Ag})$ に漸移する部分がある. I-R と岩相 II が直接接する場合 も, 黒色安山岩・灰色安山岩を挟在する場合も直線状の境界 は全く認められない.

気泡と軽石が濃集していることがある. その場合, 水平面 内において伸長した軽石や気泡の西側が岩脈壁面からわずか に離れ岩脈の中心を向くとともに，垂直面内においては上側 が岩脈壁面から離れるように傾く，また，少量の母岩由来の 包有物を含んでおり，その大部分は粒径 $1 \mathrm{~cm}$ を超えないも のの，まれに粒径 $50 \mathrm{~cm}$ を超えるものが見られる. 母岩由 来の包有物の形状は角碟状で砂岩・泥岩・片岩・チャートか らなり，いずれも母岩の四万十帯槇尾コンプレックス（大和 大峯研究グループ, 2005）で認められる岩相である。

[I-A 安山岩, I-G 花崗岩] I-R 中に包有物として多数散在 する安山岩 (I-A) は淡緑色〜淡褐色で, 花崗岩（I-G）をさ らにその内部に包有することが多い (Fig. 3.c). I-A の最大 粒径は約 $60 \mathrm{~cm}$ で, 伸長形状のものやアメーバ状のものが 多い. 多数の斑晶・気泡が肉眼で認められる. I-A に含まれ る I-G の形状も不定形を示す.

[I-Ab 黒色安山岩, I-Ag 灰色安山岩] I-Ab, I-Ag はいずれ も I-R の縁辺部に位置し, 岩相 II と I-R に挟まれるように局 所的に分布する (Fig. 2). I-Ab・I-Ag と I-R との境界は明 瞭でなく漸移している (Fig. 3.d, 3.e). また I-Ab・I-Ag と 大小の包有物を多量に含む岩相 II の安山岩（II-A）との境界 もやはり明瞭でなく波状であるが, I-Ab・I-Ag はII-A に比 べ包有物がはるかに少ない点で岩相が異なる（Fig. 3.f）.

黒色安山岩（I-Ab）は全体として S 字状に曲がったレンズ 状形態を示す (Fig. 3.d). 長さは約 $1 \mathrm{~m}$, 最大幅は約 $25 \mathrm{~cm}$ ある. I-A と異なり, 包有物は非常に少なく緻密で均質な岩 相である.

灰色安山岩（I-Ag）は全体的な形状ははっきりしないが, $\mathrm{I}-\mathrm{Ab}$ と同様, I-R と岩相 II との境界付近で局所的に分布し, 幅は最大 $60 \mathrm{~cm}$ である (Fig. 3.e). また I-A と同様, I-Ag には多数の斑晶が見られ, 最大径 $2 \sim 3 \mathrm{~cm}$ の花崗岩の包有 物を含む. 最大数 $\mathrm{cm}$ 程度の軽石や I-R と同質の包有物も少 量含まれる.

\section{（2）岩相 II}

［II -A 安山岩］岩相 II は安山岩（II-A）を主体とし，大小 の流紋岩（II-R）・花崗岩（II-G）および母岩由来の包有物 を多量に含むとともに, 局所的に流紋岩と不規則な流理構造 あるいは縞状構造を形成しミングリングする (Fig. 4.a)。岩 相 II における母岩由来の包有物の分布は不均質で, 灰色安山 岩（I-Ag）と接する部分のように局所的に濃集する（Fig. 3.e). 最大粒径は約 $1 \mathrm{~m}$ であるが, 多くは数 $10 \mathrm{~cm}$ 以下で ある (Fig. 4.b)。角礫状のものが多く, 岩相 I に含まれる母 岩由来の包有物と同様, 砂岩・泥岩・片岩・チャートからな る. このうち岩脈に直接する母岩を構成している片岩の量が 最も多い. 岩脈の南側の母岩との境界付近では母岩由来の包 有物の伸長軸の西側が岩脈の中心方向に向いている様子が観 察できる.

［II-R 流紋岩］＼cjkstart流紋岩（II-R）は岩相 I に近いところほど 多く包有されているように見えるが, 全体としての分布傾向 は露出が悪いためにはっきりしない，粒径は数 $\mathrm{mm}$ から $1 \mathrm{~m}$ を超えるものまで見られる. 包有するII - A との境界面は複 雑に入り組んで不定形状を示し，包有するII -A とミングリ ングしている (Fig. 4.c, 4.d). 包有物の内部には外形に沿つ た流理が発達する場合もある. 包有物内部で斑晶の多い部分 と少ない部分からなる縞状構造が見られるものがあり, 大き な包有物でこの特徵を持つ場合が多い. II -R には花崗岩 （II-G）や母岩由来物質が包有されるが, 径 $1 \sim 2 \mathrm{~cm}$ 程度 の比較的小さなものが多い.

[II-G 花崗岩］花崗岩（II-G）は II -A 中で不均質に分布 する. 肉眼的には花崗岩あるいは花崗斑岩と判断される. 粒 径は最大で $70 \mathrm{~cm}$ のものが見られるが, 多くは数 $\mathrm{cm}$ から $20 \mathrm{~cm}$ 程度である. 形状は円礫状が多いが角礫状のものもあ る (Fig. 4.e). その一方でいずれの形状であっても包有物と II-A の境界面は入り組んでいる場合が多い（Fig. 4.f).

\section{2. 岩石組織 \\ （1）岩相 I}

[I-R 流紋岩］＼cjkstart流紋岩は斑晶として斜長石・石英・黒雲母・ 普通輝石・不透明鉱物を含む. 斜長石は自形〜半自形を示す. 石英は融食形を示す．有色鉱物の多くは変質して緑泥石化し ている. 石基は針状〜短冊状斜長石・不透明鉱物・ガラスか らなる填間状組織で流理構造を示す。ガラスは脱ガラス化し て隠微晶質になっている. 包有物として安山岩・花崗岩と母 岩由来の片岩を含む. 安山岩は斜長石斑晶を含み, ガラス質 で不定形状のものが多い（Fig. 5.a). 花崗岩は等粒状の斜長 石と石英からなる.

[I-A 安山岩] 斑晶は斜長石・普通輝石・石英である. 斜長 石は自形〜半自形である. 普通輝石は自形・長柱状であるが 全て変質して緑泥石化している. 石英は融食形を示すととも に波動消光する. 石基は填間状〜ハイアロオフィティック組 織で, 淡褐色ガラス・少量の斜長石・顆粒状の不透明鉱物か らなる. 包有される花崗岩は等粒状の斜長石・石英からなり, 石英は波動消光する.

[I-G 花崗岩 ] 斑状である. 斑晶として石英・斜長石・黒雲 母を含む. 石英は花弁状の集合結晶となっているものが多い. 

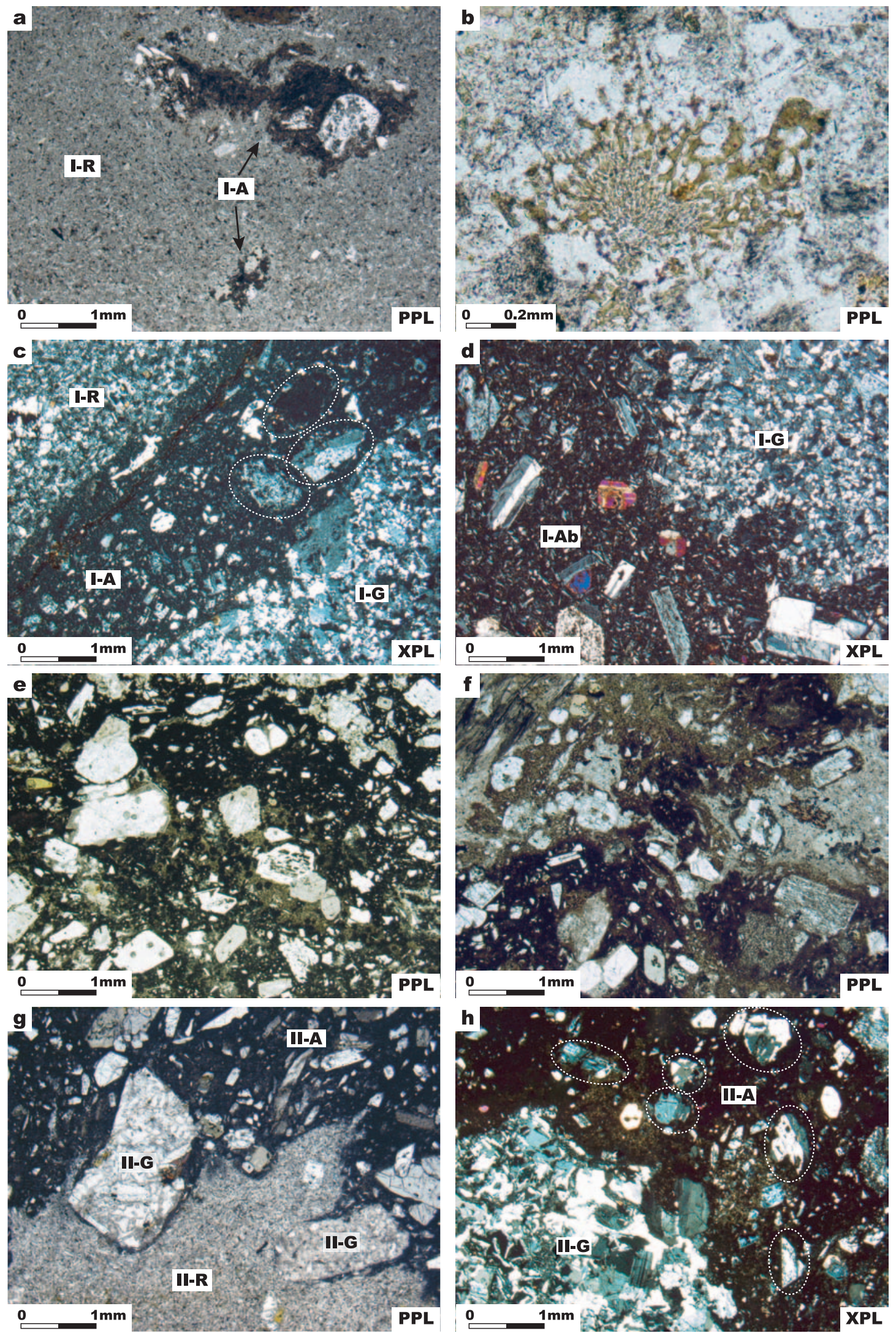

Fig. 5. Photomicrographs of the Miyataki dike. (a) I-A (andesite) enclave in I-R (rhyolite). I-A is amoeboidal in shape, and includes phenocrysts such as plagioclase. (b) Micrographic texture in I-G (granite) enclave. Dark glass replaces K-feldspar (?). (c) I-A enclave including I-G in I-R. Probable constituent minerals (circled) derived from I-G enclave are observed, and the boundary between I-A and I-G is wavy. (d) I-G enclave in I-Ab (andesite). It is amoeboidal in shape, and constituent minerals of I-G are dispersed from the margin. (e) Mingling texture in II-A. Andesitic glass is dominated, but rhyolitic glass is also observed. The rhyolitic glass includes many andesitic glass globules at the center of the photo. (f) Mingling texture of andesite and rhyolite in II-A. The darker part is andesitic glass while the lighter is rhyolitic. (g) II-R enclave in II-A. II-R itself shows fluidal shape, and the included II-G are dispersed into II-A keeping its shape unchanged. (h) II-G enclave in II-A. Probable constituent minerals (circled) derived from $I$-G enclave are observed. The boundary between $I I-A$ and $I$-G is wavy. 
波動消光を示すとともに結晶の縁辺部から鋸歯状に石英が晶 出しマイクログラフィック組織を形成している. 斜長石は自 形〜半自形で，累帯構造・アルバイト双晶を示す。一部集斑 状になっている，黒雲母は変質して緑泥石化しており，不透 明鉱物をよく伴う。斑晶間を埋める基質は長石・石英がポイ キリティック組織を示す。一部にはマイクログラフィック組 織も認められ, その長石部分が褐色ガラスに置換されている 場合が認められる (Fig. 5.b)。これらの組織に結晶内変形構 造や再結晶構造は認められない. I-G とそれを包有する I-A の境界は緩やかな波状を示し，その所々で一部の比較的大き な構成鉱物は部分的に断片化する一方，比較的小さな構成鉱 物は I-G を包有している I-A 中に散在している（Fig. 5.c）. [I-Ab 黒色安山岩 $]$ 斑晶は斜長石・普通輝石 $\cdot$ 黒雲母・石 英・不透明鉱物である. 斜長石は自形〜半自形で累帯構造を 示し, 蜂巣状構造を持つ場合もある. 普通輝石と集斑状をな すことがある. 普通輝石は自形〜半自形で長柱状〜短柱状で ある。一部に累帯構造を示すものがある。一部は緑泥石化し ている. 黒雲母は自形〜半自形であるが，ほぼ全て変質して 緑泥石化している. 不透明鉱物を含んだり, 黒雲母同士ある いは斜長石と集斑状をなすことがある. 石英に包含される場 合がある，石英は融食形を示す，不透明鉱物は不定形状であ る. 石基は填間状組織で，短冊状斜長石，針状・多角形・粒 状の不透明鉱物，短冊状普通輝石，脱ガラス化した褐色変質 物からなる．斑状でポイキリティック組織を基質にもつ不定 形状の花崗岩を包有し，それに由来すると考えられる鉱物が 花崗岩周辺に散在する (Fig. 5.d)。また内部にはネットワー ク状に緑泥石化したガラスが分布している.

[I-Ag 灰色安山岩］斑晶は自形もしくは融食形の斜長石, 緑泥石化した黒雲母・普通輝石，融食形で波動消光を示す石 英，長柱状〜短柱状の不透明鉱物である. 石基は隠微晶質な いし填間状で, 一部マイクロフェルシティックとなつている. 石基鉱物として針状斜長石・顆粒状不透明鉱物・ガラスを含 むが，ガラスの多くは緑泥石化している. 二次石英に充填さ れた気泡も多い. また二次鉱物として方解石が認められる. 含まれる包有物として不定形状の花崗岩, ブロック状の片岩 が見られる. 花崗岩は等粒状の場合と斑状でポイキリティッ ク組織の基質を示す場合がある.

\section{(2) 岩相 II}

[II -A 安山岩］＼cjkstart斑晶としては斜長石・普通輝石・黒雲母・ 石英・不透明鉱物が見られる. 斜長石は自形〜半自形のもの と融食形を示すものの 2 種類に分けられ, 前者がより多く含 まれる，前者は累帯構造やアルバイト双晶が顕著で，新鮮な 普通輝石と集斑状をなすことが多い。後者は斜長石同士で集 斑状となっていることが多い。いずれの斜長石も蜂巣状構造 を示し内部に褐色ガラス包有物を含むことが多い。普通輝石 は基本的に自形〜半自形の長柱状〜短柱状結晶であるが，新 鮮なものと変質して緑泥石化しているものがある．黒雲母は 他形で多色性ハローが認められる. 石英は他形で破片状であ る. 不透明鉱物は不定形を示す，なお，普通輝石のような長 柱状の斑晶ではクラックが発達したり, 破断している場合が 認められる. 石基は緑泥石化した淡褐色ガラスと新鮮な黒色
ガラスからなる．淡褐色ガラスは黒色ガラス中でレンズ状 . 不定形状・アメーバ状といった形状を示し, 両ガラスの境界 部分で黒色ガラスは小球状となっている (Fig. 5.e).

安山岩（II-A） は鏡下においても大小の包有物を含夕非常 に不均質である (Fig. 5.f). 確認できる包有物は砂岩・泥 岩・片岩・チャート・花崗岩・流紋岩である，これらのうち 砂岩・泥岩・片岩・チャートはいずれも母岩を構成する岩石 種であり，ブロック状の形状である．花崗岩には不定形状の ものが多く，いずれも石英・斜長石・黒雲母を含みポイキリ ティック組織の基質を持つ. 流紋岩は不定形状である。流紋 岩には普通輝石のコロナを持つ融食形の石英, 斜長石, 緑泥 石化した黒雲母, 不透明鉱物の斑晶が含まれ，その石基はガ ラス質であるが変質して隠微晶質あるいはマイクロフェルシ ティック組織を示す。流紋岩はさらに花崗岩を包有するが, 一部で花崗岩が流紋岩から II -A に突出している. その場合 でも包有される場合と形状に差はない（Fig. 5.g).

[II -R 流紋岩］＼cjkstart石英のみを斑晶として含む．融食形である が，花弁状の集斑晶をなすことがある．また波動消光を示す． 石基は填間状組織で, 針状〜短冊状の斜長石が流理組織を示 す. 少量の顆粒状不透明鉱物も含まれる. 不定形の気泡も見 られるが, 波動消光する二次石英に充填されている. また包 有物として花崗岩を含み, その花崗岩包有物の組織には全体 として他形の斜長石の集合である場合, 斜長石・石英・黒雲 母の集合である場合，細粒の石英の集合である場合がある.

[II -G 花崗岩 ] 斑状花崗岩である. 斑晶は石英・斜長石・ 黒雲母である．石英は花弁状の集合結晶であることが多い． またその周囲では鋸歯状に晶出した石英が長石とマイクログ ラフィック組織をなす。斜長石は自形〜半自形で, 累帯構造 を示し，一部集斑状である。部分的にソーシュライト化が著 しい，黒雲母は緑泥石化していることが多いが，包有物の粒 径が大きい場合には内部に新鮮な黒雲母が多く見られる. 斑 晶間の基質は石英と長石からなるポイキリティック組織であ る.一部にはマイクログラフィック組織も認められ, その長 石部分が褐色ガラスに置換されていることがある．褐色ガラ スはIII-G 中にネットワーク状に分布する。これらの斑晶・ 基質には結晶内変形構造や再結晶構造は認められない. 包有 物の周囲の II -A 中には包有物由来と考えられる鉱物が散在 する (Fig. 5.h).

\section{3. 全岩化学組成}

宮滝岩脈を構成する各岩相について全岩の主成分・微量元 素組成を求めた。だしII-A については非常に不均質であ り, 分析用試料を単独で分離することが困難であったので分 析対象としなかった. 分析は東京大学地震研究所の蛍光 X 線分析装置 (Phillips PW2400) により希釈率 1:2 のガラス ビードを用いて行った. 方法の詳細は谷ほか (2002) に従っ た. 分析結果を Table 1 に示した.

Fig. 6.a には全アルカリーシリカ図を示すとともに, 宮滝 地域に隣接する樫尾地域の岩脈のうち D20（立武岩一流紋岩 複合岩脈）の流紋岩部とそこに含まれる花崗岩包有物の分析 值（新正ほか, 2003）とD21（デイサイト岩脈）の分析值 （和田ほか, 2000）も併せて示した. 宮滝岩脈を構成するもの 
Table 1. Bulk rock chemical compositions of rhyolites, andesites and granites from the Miyataki dike.

\begin{tabular}{|c|c|c|c|c|c|c|c|c|}
\hline \multirow[b]{2}{*}{ (wt.\%) } & \multicolumn{5}{|l|}{ Facies I } & \multicolumn{3}{|c|}{ Facies II } \\
\hline & I-R & I-R & I-Ab & I-Ag & I-A & I-G & II-R & II-G \\
\hline $\mathrm{SiO}_{2}$ & 69.49 & 69.56 & 57.51 & 60.07 & 60.14 & 69.14 & 71.33 & 70.02 \\
\hline $\mathrm{TiO}_{2}$ & 0.84 & 0.68 & 1.74 & 1.41 & 1.83 & 0.71 & 0.59 & 0.70 \\
\hline $\mathrm{Al}_{2} \mathrm{O}_{3}$ & 14.16 & 14.33 & 16.23 & 15.14 & 16.10 & 13.61 & 13.27 & 13.81 \\
\hline $\mathrm{Fe}_{2} \mathrm{O}_{3}^{*}$ & 4.43 & 4.21 & 7.97 & 7.32 & 7.86 & 3.80 & 3.43 & 3.93 \\
\hline $\mathrm{MnO}$ & 0.06 & 0.08 & 0.14 & 0.14 & 0.11 & 0.04 & 0.05 & 0.04 \\
\hline $\mathrm{MgO}$ & 1.91 & 1.31 & 3.46 & 3.62 & 4.45 & 1.34 & 1.24 & 1.38 \\
\hline $\mathrm{CaO}$ & 0.97 & 1.70 & 6.59 & 3.52 & 2.28 & 0.72 & 0.89 & 0.72 \\
\hline $\mathrm{Na}_{2} \mathrm{O}$ & 2.86 & 2.94 & 2.43 & 2.60 & 3.61 & 2.05 & 2.59 & 2.12 \\
\hline $\mathrm{K}_{2} \mathrm{O}$ & 4.16 & 4.19 & 1.85 & 2.45 & 1.30 & 5.26 & 5.02 & 5.36 \\
\hline $\mathrm{P}_{2} \mathrm{O}_{5}$ & 0.18 & 0.16 & 0.33 & 0.26 & 0.35 & 0.16 & 0.14 & 0.17 \\
\hline Total & 99.04 & 99.14 & 98.26 & 96.52 & 98.03 & 96.83 & 98.55 & 98.25 \\
\hline Rock type** & Rhyolite & Rhyolite & Ande site & Ande site & Ande site & Rhyolite & Rhyolite & Rhyolite \\
\hline \multicolumn{9}{|l|}{ (ppm) } \\
\hline $\mathrm{Sc}$ & 10 & 9 & 21 & 17 & 16 & 9 & 6 & 8 \\
\hline $\mathrm{V}$ & 77 & 41 & 138 & 126 & 154 & 46 & 41 & 52 \\
\hline $\mathrm{Cr}$ & 37 & 22 & 62 & 59 & 61 & 12 & 18 & 22 \\
\hline Co & 9 & 8 & 23 & 20 & 21 & 8 & 8 & 7 \\
\hline $\mathrm{Ni}$ & 12 & 7 & 23 & 23 & 27 & 10 & 7 & 11 \\
\hline $\mathrm{Zn}$ & 52 & 50 & 82 & 83 & 101 & 58 & 37 & 74 \\
\hline $\mathrm{Ga}$ & 15 & 17 & 19 & 18 & 20 & 15 & 13 & 17 \\
\hline $\mathrm{Rb}$ & 145 & 132 & 43 & 70 & 44 & 195 & 159 & 136 \\
\hline $\mathrm{Sr}$ & 196 & 240 & 297 & 238 & 205 & 199 & 211 & 214 \\
\hline $\mathrm{Y}$ & 19 & 32 & 32 & 34 & 26 & 28 & 29 & 25 \\
\hline $\mathrm{Zr}$ & 209 & 234 & 195 & 197 & 206 & 252 & 223 & 249 \\
\hline $\mathrm{Nb}$ & 16 & 17 & 21 & 19 & 23 & 17 & 16 & 16 \\
\hline $\mathrm{Ba}$ & 654 & 616 & 402 & 495 & 300 & 719 & 775 & 777 \\
\hline $\mathrm{Pb}$ & 11 & 20 & 16 & 14 & 17 & 21 & 12 & 25 \\
\hline Th & 10 & 11 & 5 & 8 & 10 & 7 & 10 & 12 \\
\hline Note & Cent er & Margin & & & & & & \\
\hline
\end{tabular}

(a)
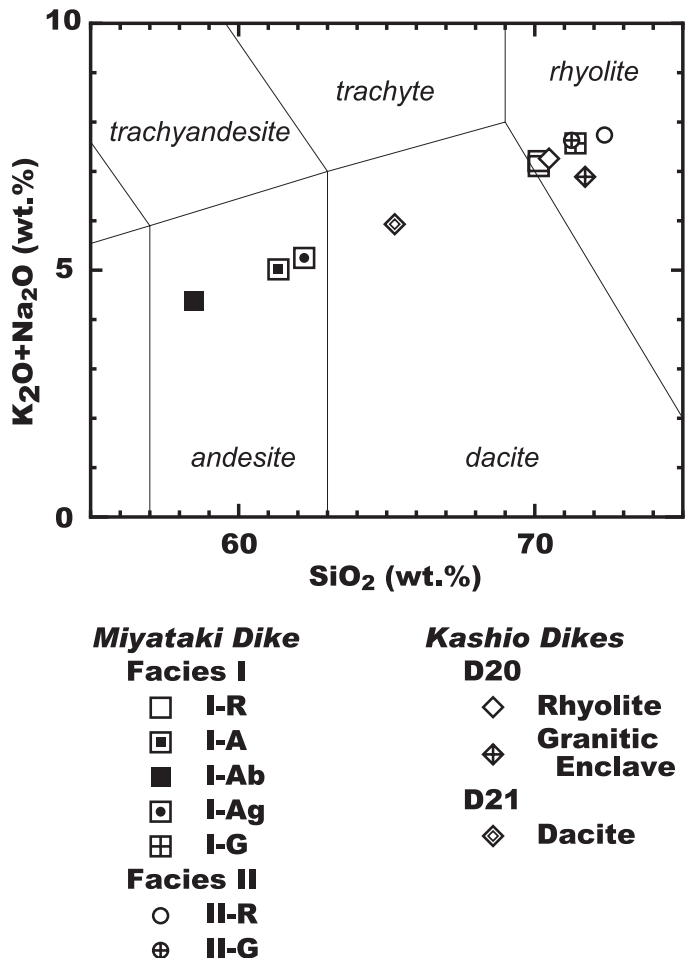

D21

- Dacite (b)

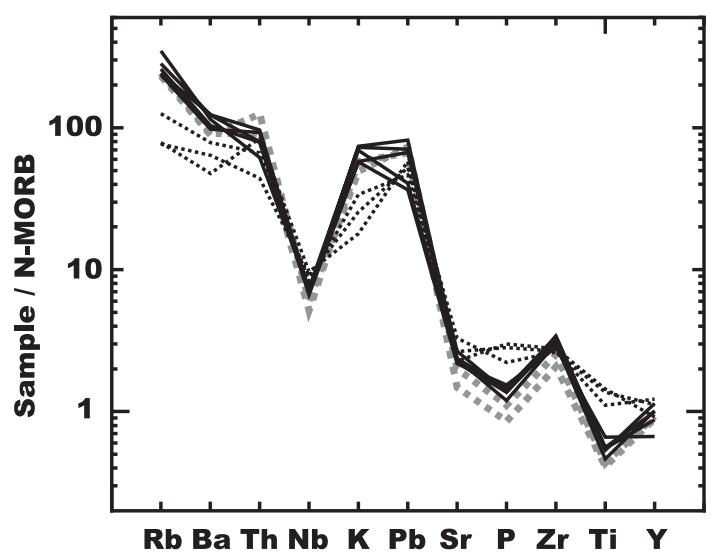

Miyataki Dike

Kashio Dike (D20)

Rhyolite
Granite

Rhyolite

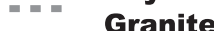

Andesite

Fig. 6. Results of chemical analyses. (a) Total-alkali vs. silica diagram (Le Maitre, 1989), showing that the Miyataki dike is of andesitic and rhyolitic in major element composition, and that these data plots make a linear chemical variation, suggesting magma mixing and/or mingling. (b) Spider diagram, normalized to N-MORB (Sun and McDonough, 1989). Data pattern for felsic counterparts of the Miyataki dike are consistent with one another and those from D20 composite dike at Kashio (Shinjoe et al., 2003), and the pattern for the intermediate counterparts are consistent with one another. 

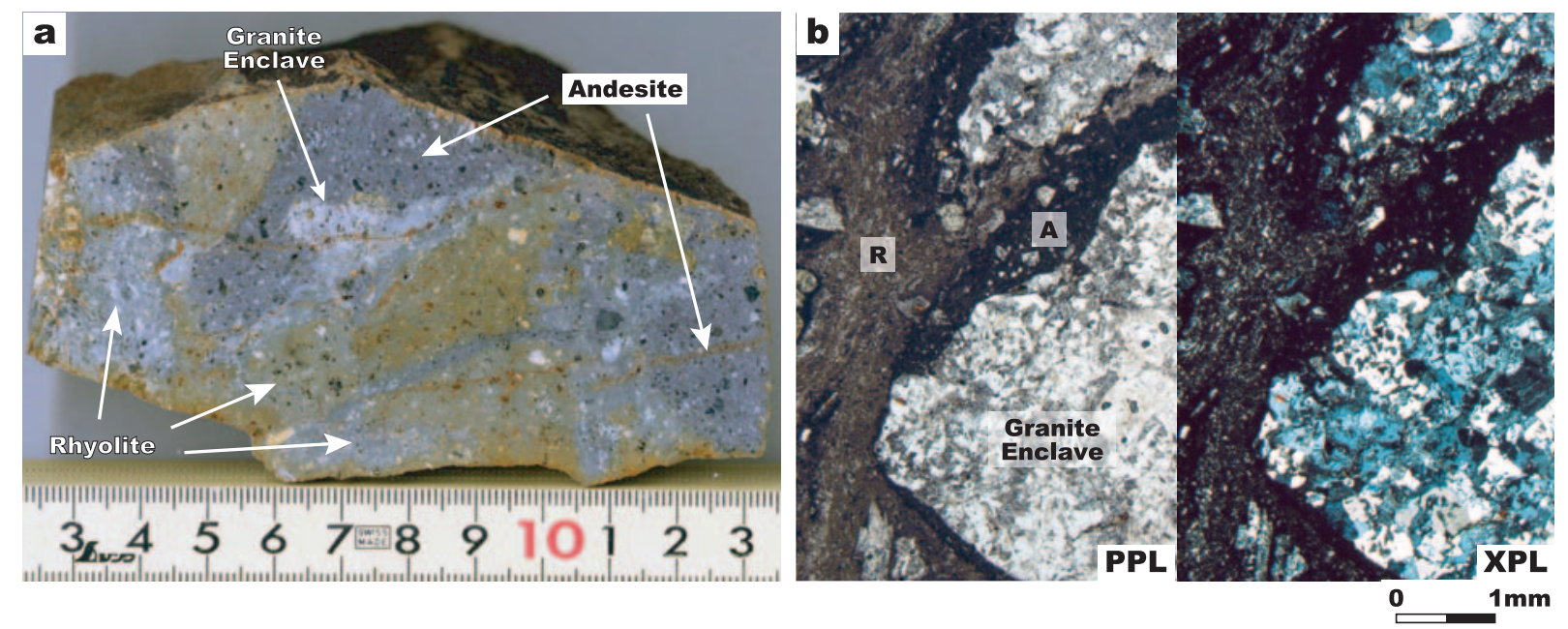

Fig. 7. Mingling structure observed in D21 dacite dike exposed at Kashio near Miyataki. (a) A section of a sample from the Kashio dike D21. Sample is ca.11cm wide. (b) Thin section of the dike D21 (A: andesite; R: rhyolite). Andesite and rhyolite are mingled together with amoeboidal grantite enclave. The granite enclave shows a similar texture as I-G and II-G enclaves in the Miyataki dike (Fig. 5.c, 5.h).

のうち I-A，I-Ab，I-Ag は安山岩組成を示し，残る I-R，IG， II-R，II-G はいずれも流紋岩組成である．宮滝岩脈の岩 石は全体として直線的なトレンドを示す。さらに宮滝岩脈の 流紋岩組成を示すものは樫尾地域の D20 の流紋岩および花 崗岩包有物の組成と類似している。一方, 樫尾地域の D21 のデイサイト組成の岩石は, 宮滝岩脈の安山岩組成と流紋岩 組成の中間に位置し，両者を結ぶトレンド上にある.

Fig. 6.b に宮滝岩脈の Rb, Ba, Th, Nb, K, Pb, Sr, P, $\mathrm{Zr}$ ，Ti，Yのスパイダー図を示した。同図には樫尾地域の D20 岩脈の流紋岩部と花崗岩包有物の值（新正ほか, 2003） も示し，宮滝岩脈との微量元素組成の比較を行つた。規格化 には島弧火山岩としての特徵を明確化するため N-MORB の 值（Sun and McDonough, 1989）を用いた. 宮滝岩脈試料 の值は岩質に関係なく全体として右下がりのパターンを示す とともに Nb の顕著なトラフが認められる. これは多くの島 弧火山岩に見られる特徵と同じものである。一方，宮滝岩脈 試料のうち, 安山岩組成のものは流紋岩組成のものより $\mathrm{Rb} \cdot \mathrm{Ba} \cdot \mathrm{K}$ に乏しく, P ・ Ti に富む，樫尾地域の D20 岩 脈の流紋岩部と花崗岩包有物の微量元素組成は宮滝岩脈の流 紋岩組成のものとスパイダー図上でもよく一致している.

考察

\section{1. 宮滝岩脈の岩相}

従来，宮滝岩脈は火砕岩からなるとされてきたが，火砕岩 からなることを示す観察事実は全く記載されていない（日本 の地質「近畿地方」編集委員会, 1987; 大和大峯研究グルー プ,1994)。これまでの研究で火砕岩とされてきた理由は，流 紋岩（岩相 I）が発泡していること，緻密なガラス質岩相 （岩相 II）が流紋岩や母岩由来の包有物を多数含むことのた めであろう。しかし, 宮滝岩脈は全体として流紋岩と安山岩 がミングリングした構造を持つ火山岩からなると説明でき る.すなわち, 野外での産状・岩石組織の記載で示した以下
の観察事実が流紋岩マグマと安山岩マグマが岩脈内でミング リングしたことを強く示唆する.

（1）不定形状の岩相 I（流紋岩）は岩相 II（安山岩）に全体 として包有され (Fig. 2), 両者の境界面は激しく入り組 んでいること (Fig. 3.b).

（2）岩相 I では流紋岩（I-R）が不定形状の安山岩（I-A）を 包有すること（Figs. 3.c, 5.a, 5.c).

（3）岩相 II では安山岩（II -A）が不定形状の流紋岩（II -R） を包有し (Figs. 4.a, 4.c, 4.d, 5.g), 鏡下においても淡 褐色流紋岩質ガラスと黒色安山岩質ガラスが互いを包有 し，かつ流理構造を形成していること（Fig. 5.e, 5.f).

なお，岩相 II の安山岩（II-A）にはクラックが発達したり 破断した斑晶が認められるが，そのガラス質マトリックスは 火山ガラス片の集合あるいはそれが溶結した組織ではなく， マグマが破砕されたとは考えられない.クラックが発達した り破断した斑晶は岩脈中で流動・ミングリングするマグマに よって変形・破壊されたものであろう。また流紋岩（I-R, II -R）中の気泡はマグマの上昇・減圧によって発泡したもの と考えられる.

一方, 宮滝の東方に隣接する樫尾地域の岩脈 D21（和田ほ か, 2000）の露頭観察では流紋岩・花崗岩の包有物を安山岩 質岩中に確認できる. 流紋岩包有物は伸びた不定形状で, 流 理構造を作っている所もある (Fig. 7.a). 花崗岩包有物も不 定形状で, 岩石組織としては斑状であり, ポイキリティック 組織の基質をもつとともに一部にはマイクログラフィック組 織も見られる (Fig. 7.a, 7.b). いずれも宮滝岩脈の安山岩質 の岩相 II で見られるミングリング構造に酷似し，そこに含ま れる流紋岩・花崗岩両包有物の特徵と一致する。つまり, D21 岩脈は宮滝岩脈の延長部である可能性が高い。和田ほか （2000）はD21 岩脈からデイサイト組成の全岩分析值を報告 しているが，これは安山岩質の部分と流紋岩質の部分のミン グリングした試料を分析したためにデイサイト組成となつた 
ものと解釈できる．D21 の全岩化学組成は全元素において宮 滝岩脈の組成が示すトレンド上にあり（Fig. 6.a)，ミングリ ングによるとする考えと調和的である.

\section{2. 岩脈形成過程}

火道つまり岩脈内でのマグマ・ミングリングについての記 載例は多くない. Mull 島の Loch Ba 環状岩脈 (Walker and Skelhorn, 1966; Marshall and Sparks, 1984）ではフェルサ イト中に苦鉄質包有物が wisp 状・streak 状の形態で含ま れ，さらに安山岩とフェルサイトからなる細かい縞状構造す なわちミングリングが局所的に発達する. Skye 島の Kilchrist 環状岩脈でも同様の構造が報告されている（Bell, 1983)。ニューハンプシャー州の Ossipee 環状岩脈では縞状 構造をもつ玄武岩と破片状の流紋岩がミングリングし，岩脈 縁辺部で両者が玄武岩質安山岩の混成岩を形成する (Kennedy and Stix, 2007). これらの構造はいずれもカルデ ラ形成時のカルデラ床の沈降に伴いマグマ溜まり中の不均質 混合マグマが環状岩脈に注入されたものと考えられている. 一方, コロラド州の San Isabel batholith ではランプロファ イアと花崗岩からなる複合岩脈が見られる. Noblett and Staub（1990）によれば，岩脈中でのランプロファイアと花 崗岩の量比は走向方向に大きく変化し, ランプロファイア中 に渦巻き状パターン（swirling pattern）を示す花崗岩包有 物が含まれる一方, 花崗岩中の苦鉄質包有物がさらに花崗岩 を包有する.このような構造は花崗岩バソリス周辺を上昇し てきたランプロファイア・マグマとバソリスを作っている花 崗岩マグマが混合したためとされている，以上のように，マ グマ・ミングリング現象の認められる岩脈はいずれもマグマ 溜まり中で不均質混合したマグマがそのまま岩脈中を上昇し てきたものと解釈されきた.

宮滝岩脈の場合, 安山岩と流紋岩が互いを包有するミング リング構造が認められる.さらには花崗岩も安山岩・流紋岩 に包有される．まず岩相 II の安山岩（II-A）に含まれる流紋 岩包有物（II-R） は岩相 I の流紋岩（I-R）から分離したも のと考えられる. これを支持する観察事実として以下のこと が挙げられる。

（1） I-R と II -A の境界では I-R が II -A と複雑に包有し合う箇 所が見られること (Fig. 3.b).

(2) I-R とII-R の岩石組織が類似すること.

（3） I-R とII-R は同じ組織をもつ花崗岩包有物（I-G， II-G） を包有すること.

また， II-R と II-A の境界付近では不定形状の II -R 中の II - G がII-A 中に突出している (Fig. 5.g)。 II -G の形状は突出す る部分でも全体が包有される部分でも差はなく， II -G は II $\mathrm{R}$ から形状を保つたまま分離することが推定できる。つま り，岩相 I から分離した I-R ・ I-G が岩相 II 取り込まれて II -R・II-G を形成したと説明可能である．以上のことは岩 脈火道内でも安山岩マグマと流紋岩マグマはミングリングを 続けていたことを強く示唆する.

黒色安山岩（I-Ab）・灰色安山岩（I-Ag）は岩相 I の縁辺 部に局在する. I-Ab・I-Ag と I-R の境界は波状で漸移して いる一方, $\mathrm{I}-\mathrm{Ab}$ ・ I-Ag とII-A との境界は漸移的であるもの
の II -A には包有物が多く, I-Ab・I-Ag と II -A との境界は I-R とのそれよりはるかに明瞭である. また, I-Ab と I-Ag は花崗岩を包有する点と母岩由来物質をほとんど包有しない 点において同じ特徵を持つ.これらの特徽は I-R 内部の I-A と同じである。しかし，全岩化学組成においてはI-Ab と I$\mathrm{Ag}$ は $\mathrm{SiO}_{2}$ 量で数\%の差が認められる一方, I-Ag の組成值は I-A とほぼ同じである (Fig. 6.a; Table 1). 以上のことは, I$\mathrm{Ab} ・ \mathrm{I}-\mathrm{Ag}$ はII -A ではなく I-R と成因的に密接に関係して岩 脈内で流動してきたこと，言い換えれば I-Ab・I-Ag が I-R とともにひとつの大きな包有物として火道中を流動してきた ことを示唆するとともに, I-R 内部に含まれる I-A が I-Ag と 同じマグマに由来するものであることを示唆する.つまり, 火道に注入される以前から安山岩マグマは流紋岩マグマとミ ングリングを起こしていた可能性が高い. また，I-Ab は IA ・ I-Ag と比較して最も苦鉄質な組成を示し（Fig. 6.a, Table 1), 最も均質で緻密な岩石組織をもつ. その中に不定 形状の花崗岩包有物（I-G）を含むこと（Fig. 5.d）からすれ ば，I-Ab を作った安山岩マグマは他のマグマと混合する前に 直接花崗岩に接触しその断片を包有した可能性が高い. I-Ab が I-R の周辺に局所的に分布する理由としては宮滝岩脈の主 要な部分を占める安山岩（II-A）の一部である可能性が考え られる。 つまり， I-R と接触しているII-A の中で母岩由来物 質やその他の包有物と不均質混合しなかった部分が I-Ab で あるという考え方である. その可能性を支持する観察事実と して I-Ab とII-A には新鮮な普通輝石が含まれるが，それ以 外の岩相に同様に新鮮なものは含まれないことが挙げられ る. I-Ab がII-A のように流紋岩・母岩由来物質と火道内で ミングリングを起こさなかったのは岩脈貫入の初期段階で低 温の I-R と接触・急冷して一体化し, その後 I-R とともに上 昇してきたからかもしれない.

ところで, 岩脈に包有される花崗岩（I-G, II-G） は形状・ 岩石組織から, 比較的高温な状態にあった深成岩体に由来す ると考えられる. 花崗岩包有物は不定形状 (Figs. 3.c, 4.e, 4.f）であるだけでなく, 包有物周辺に包有物由来と考えられ る鉱物が散在している（Figs. 5.c, 5.d, 5.h)。一方で, 包有 物そのものには固体状態での変形を示唆する結晶内変形構造 や, 安山岩あるいは流紋岩からの熱的影響を示唆する再結晶 構造は全く認められない. したがって, 包有物は固結状態で 安山岩・流紋岩に取り込まれたと見られるが，比較的温度の 高い状態にあった可能性が高い. 宮滝周辺地域には露出する 花崗岩体は知られていないが，隣接する樫尾地域の玄武岩一 流紋岩複合岩脈（和田ほか, 2000）の流紋岩部に包有される 花崗岩包有物から中期中新世の伏在岩体の存在が推定され, それは大峯花崗岩質岩に相当する岩体のひとつと考えられて いる(新正ほか, 2003). 樫尾複合岩脈の花崗岩包有物もそれ を包有する流紋岩との境界は入り組んだ波状を示しており， 高温状態で流紋岩マグマに取り込まれたものと推定されてい る. また, 宮滝岩脈の流紋岩・花崗岩と樫尾地域の D20 岩 脈のそれらはともに同じ微量元素組成パターンを示す（Fig. 6.b). 花崗岩の全岩組成は必ずしもメルト組成を表すもので はないが，宮滝・樫尾両岩脈の花崗岩包有物には集積岩に特 


\section{Surface}

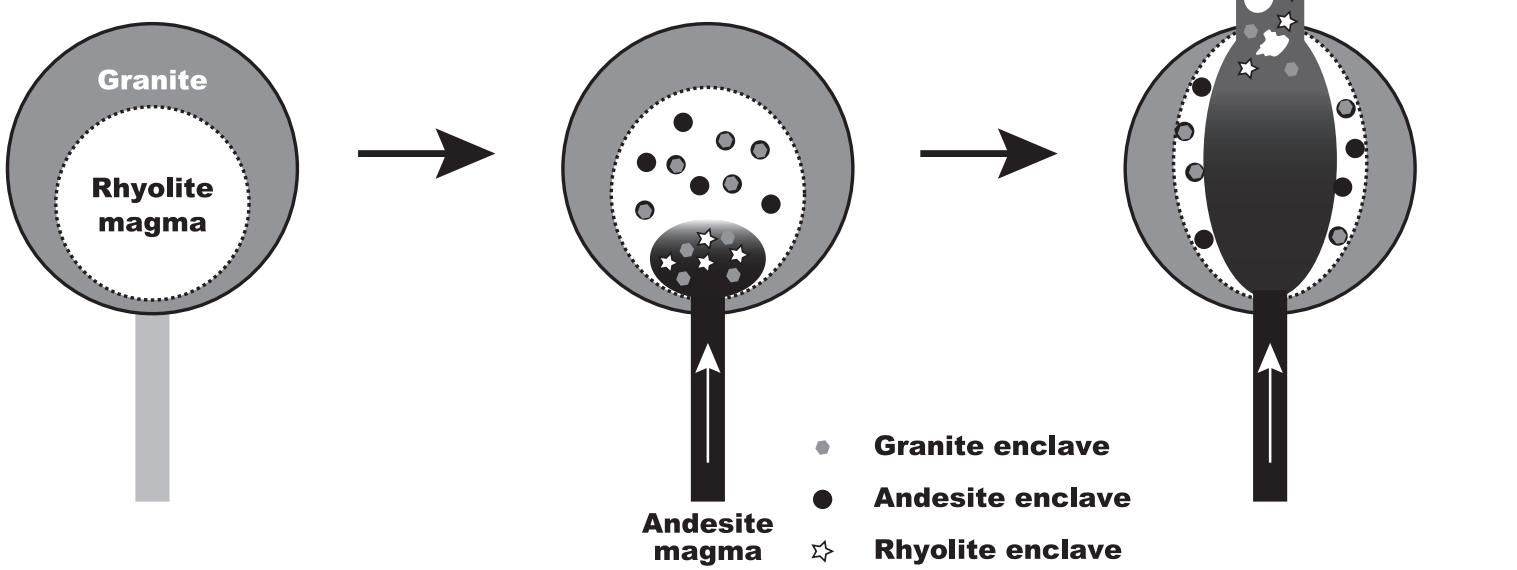

Fig. 8. Schematic model for the emplacement of the Miyataki dike.

徵的な組織がいずれも見られず，宮滝と樫尾の岩脈に含まれ る流紋岩・花崗岩の起源が同じものであると考えることは差 し支えない,つまり, 樫尾の複合岩脈の流紋岩マグマと同様, 宮滝岩脈をつくつた安山岩マグマは地下浅所の高温状態にあ る深成岩体と接触しミングリングしたことが推定できる．特 に宮滝岩脈の場合，岩相 I の流紋岩（I-R）中の安山岩（I-A） が花崗岩（I-G）を包有することから，安山岩マグマが冷却 途中の高温花崗岩体と直接接触できたと考えられる.

以上をまとめると，宮滝岩脈を形成した安山岩・流紋岩両 マグマと花崗岩体の関係すなわち岩脈形成過程には以下のよ うなモデル（Fig. 8）を考えることができる.

（1）地下浅所に貫入していた花崗岩体（大峯花崗岩質岩の一 部である可能性が高い) があり，その周縁部は冷却によ つて固結が進行していたが (I-G・II-G), 中心部ほど冷 却が遅く半固結〜未固結状態にあった (I-R).

（2）花崗岩体に安山岩マグマ（I-Ab）が貫入し，岩体周縁部 の固結した花崗岩（I-G・II-G）を取り込むと同時に, 岩体中心部の未固結の流紋岩マグマ (I-R, II-R) と不均 質混合（ミングリング）を起こした. その際, 安山岩マ グマの断片・包有物（I-Ag, I-A）を形成した.

（3）さらに安山岩マグマが貫入し花崗岩体を突き破り上昇し 岩脈を形成した。 その際, 安山岩マグマは, 火道形成に 伴う多量の母岩由来物質を取り込夕ながら, 安山岩マグ マの断片・包有物（I-Ag, I-A）を伴つた流紋岩マグマの 包有物（I-R, II -R） と火道内で不均質混合すなわちミン グリングして定置した（II-A).

以上のモデルの時間スケールについての情報は今のところ得 られていない。しかし，ミングリング現象は定性的にはある マグマが別のマグマに注入されて十分時間が経過し均質にな る前におこると考えられており（Blake and Koyaguchi,
1991), 宮滝岩脈の場合も同様に安山岩マグマが花崗岩体に 貫入したあと比較的短時間のうちに起こつたと考えることが できるだろう.

\section{3. 紀伊半島における中新世火成活動}

紀伊半島の西南日本外帯における中新世火成岩体の特徵の ひとつとして珪長質マグマの活動が卓越するという認識が一 般的である. これは大峯・熊野両酸性岩類が広く分布し, 比 較的研究が進んでいることによるのだろう. しかし, 宮滝岩 脈を形成したのは中間質マグマと珪長質マグマである. 最近 の研究によれば, 紀伊半島に分布する中期中新世火成岩体の 形成には，珪長質マグマのみならず苦鉄質〜中間質マグマが 寄与していることが明らかにされつつある（例えば，中奥火 砕岩岩脈: 和田ほか, 2004). しかも, 樫尾複合岩脈（和田ほ か, 2000）や川上村中奥の D4 岩脈（和田・新正, 2004）の ように，珪長質マグマと中間質・苦鉄質マグマが同時に活動 して複合岩脈を形成していることが多く, 宮滝岩脈の産状に 示されるように直接混合が可能な状況にあったことを強く示 唆している.

宮滝の位置は瀬戸内火山岩類と外帯酸性岩類のほぼ中間に 位置する. 中田・高橋（1979）は化学組成の変化が連続的で あることから, 両者を一連の火成活動の産物と見なしている. また近年出されている多くの年代デー夕の総括から両者の活 動には時間的間隙がないことが強く支持されている（例えば, 角井, 2000; 新正 ・角井, 2000; Sumii and Shinjoe, 2003). 瀬戸内火山岩類においても珪長質マグマと中間質・苦鉄質マ グマが相伴って活動しているが，両者の活動に時間的にずれ があるという主張（Tatsumi et al., 2001）と同時期の活動で あるとの主張（例えば, 吉川, 1997; 星ほか, 2002）がある. 宮滝岩脈は中央構造線より南で, なおかつ大峯花崗岩質岩と 近接する位置にあり, 瀬戸内火山岩類とは直接比較できない. 
しかし，少なくともこの地理的位置では珪長質マグマと中間 質・苦鉄質マグマは同時期に活動していたことを意味する.

一方で，先述したように，従来の火道内ミングリング現象 の研究例では, カルデラやバソリスといつた巨大なマグマ溜 まりに伴ってミングリング現象の見られる岩脈が形成されて いるように見える．近年，宮滝岩脈の周辺でも巨大マグマ溜 まりの存在が推定されている（梅田ほか, 2003; 三浦・和田, 2007)。このことからすれば宮滝岩脈でのミングリング現象 は，他の複合岩脈（和田ほか, 2000; 新正ほか, 2003; 和田・ 新正, 2004）の成因と共に, 紀伊半島における中期中新世の 巨大マグマ溜まり内でのマグマ・プロセスを理解するための 重要な鍵となる可能性がある.

\section{ま と め}

奈良県吉野町，宮滝岩脈の産状と岩石組織の観察から，同 岩脈では安山岩マグマと流紋岩マグマがミングリングを起こ していたことが明らかとなった。 また同岩脈に包有される花 崗岩は宮滝の近傍地域に花崗岩からなる伏在岩体が存在する ことを強く示唆し，そこで安山岩マグマ・流紋岩マグマ・花 崗岩体の三者が互いに接触しミングリングを起こした可能性 が高い。岩脈はマグマ溜まりから地表へマグマをもたらし, マグマの混合・ミングリングを起こす場のひとつと見なされ てきた（例えば, 小屋口，1986）。宮滝岩脈はその一例と考え られ，火道を上昇するマグマの挙動や混合過程の理解に重要 なものと考えられる.

現在, 少なくとも紀伊半島においては火山地質学・年代 学・地球化学からのアプローチにより, 熊野・大峯岩体に代 表される珪長質マグマ活動以外にも異なる組成のマグマ及び その活動の詳細が明らかにされつつある。 今後さらにこれら の手法を用いて火成活動の実態の解明を続けると同時に，詳 細な岩石学的検討によりそれぞれのマグマの特徵付けが必要 である.これによって火成活動とテクトニクスとの関連の解 明が期待できるだろう.

\section{謝}

辞

本研究は藤田の奈良教育大学大学院教育学研究科平成 16 年度修士論文の一部である。蛍光 X 線分析では折橋裕二氏 （東京大学地震研究所）のお世話になった. 星 博幸氏（愛 知教育大学）には本特集号へ投稿する機会をいただいた。 三 浦大助氏（電力中央研究所）には粗稿への御意見をいただい た. 編集委員の角井朝昭氏（産業総合技術研究所）および査 読者の沢田順弘氏（島根大学）と下司信夫氏（産業技術総合 研究所）のコメントによって原稿は大幅に改善された。本研 究には平成 $15 \sim 17$ 年度東京大学地震研究所特定共同研究 （B）「火成活動から見た西南日本弧の中新世テクトニクス」 （課題番号: 2003-B-03, 研究代表者:新正裕尚）からの予算を 使用した. 以上，記して感謝したい.

\section{引用 文 献}

Bell, B.R., 1983, Significance of ferrodioritic liquids in magma mixing processes. Nature, 306, 323-327.

Blake, S., and Koyaguchi, T., 1991, Insights on the magma mixing model from volcanic rocks. In Didier, J. and Barbarin, B., eds., Enclaves and Granite Petrology (Developments in Petrology 13), Elsevier, Amsterdam, 403-413.

Hibbard, M.J., 1995, Petrography to Petrogenesis. Prentice Hall, New Jersey, $608 \mathrm{p}$

星 博幸・岩野英樹 - 檀原 徹, 2002, 瀬戸内火山岩類のフィッショ ン・トラック年代測定:近畿地方, 二上層群の例. 地質雑, 108, 353365 .

川畑 博 - 周藤賢治, 2000, 四国北東部, 観音寺周辺に分布する瀬戸内 火山岩類の地質. 地質雑, 106, 670-688.

Kennedy, B., and Stix, J., 2007, Magmatic processes associated with caldera collapse at Ossipee ring dyke, New Hampshire. Geol. Soc. Am. Bull., 119, 3-17.

小屋口剛博, 1986, 苦鉄質マグマと珪長質マグマの混合機構一不均質な マグマの成因一. 火山第二集, 30, S41-S54

Le Maitre, R. W., ed., 1989, A Classification of Igneous Rocks and Glossary of Terms - Recommendations of the International Union of Geological Sciences Subcommission on the Systematics of Igneous Rocks -. Blackwell Sci. Pub., Oxford, 193p.

Marshall, L.A., and Sparks, R.S.J., 1984, Origin of some mixed-magma and net-veined ring intrusions. Jour. Geol. Soc. London, 141, 171-182.

三浦大助・和田穣隆, 2007 , 西南日本弧前縁の圧縮テクトニクスと中 期中新世カルデラ火山. 地質雑, 113, 283-295 本特集号)

中田節也・高橋正樹, 1979, 西南日本外帯・瀬戸内区における中新世の 中性〜珪長質マグマの化学組成広域的変化. 地質雑, 85, 571-582.

日本の地質「近畿地方」編集委員会編, 1987, 日本の地質 6: 近畿地方. 共立出版, 297p.

Noblett, J.B., and Staub, M.W., 1990, Mid-Proterozoic lamprophyre commingled with late-stage granitic dikes of the anorogenic San Isabel batholith, Wet Mountains, Colorado. Geology, 18, 120-123.

Shelley, D., 1992, Igneous and Metamorphic Rocks Under the Microscope-Classification, Textures, Mirostructures and Mineral Preferred Orientations. Chapman \& Hall, London, 445p.

新正裕尚 - 角井朝昭, 2000 , 外帯酸性岩の成因. 月刊地球 (号外), no.30, 222-226.

新正裕尚 - 和田穣隆 - 折橋裕二 - 角井朝昭 - 中井俊一, 2003, 岩脈中 の花こう岩質包有物のジルコン U-Pb 年代から推定される奈良県 吉野地域の中央構造線南方に伏在する中新世花こう岩質岩体. 地 質雑, 109, 689-696.

角井朝昭, 2000 , 瀬戸内海西部地域における中新世瀬戸内火山岩類の $\mathrm{K}-\mathrm{Ar}$ 年代. 地質雑, 106, 609-619.

Sumii, T., and Shinjoe, H., 2003, K-Ar ages of the Ohmine Granitic Rocks, south-west Japan. Island Arc, 12, 335-347.

Sun, S.-S., and McDonough, W.F., 1989, Chemical and isotopic systematics of oceanic basalts: implications for mantle composition and processes. In Saunders, A.D. and Norry, M.J., eds., Magmatism in the Ocean Basins, Geol. Soc. Spec. Pub., 42, 313-345.

谷 健一郎・折橋裕二・中田節也, 2002 , ガラスビードを用いた蛍光 X 線分析装置による珪酸塩岩石の主・微量成分分析: 3 倍 - 6 倍・ 11 倍希釈ガラスビード法の分析制度の評価. 東京大地震研究所技 術報告, 8, 26-36.

Tatsumi, Y., Ishikawa, N., Anno, K., Ishizaka, K., and Itaya, T., 2001, Tectonic setting of high-Mg andesite magmatism in the SW Japan arc: KAr chronology of the Setouchi volcanic belt. Geophys. Jour. Int., 144, 625-631

梅田浩司・上原大二郎・小川康雄・工藤 健 - 角田地文, 2003, 広帯域 MT 法による紀伊半島の中新世珪長質火成岩体の深部構造. 火山, 48, 461-470.

和田穣隆 - 安藤将史 - 東山岳広, 2000 , 紀伊半島中央部, 奈良県川上村 と吉野町に分布する岩脈のマグマ流動方向. 奈良教育大紀要, 49, 47-57.

和田穣隆 - 丸目絋輔・新正裕尚, 2004, 奈良県川上村中奥に分布する 火砕岩（tuffite）岩脈から見出された苦鉄質〜中間質の本質岩片 とその意義. 奈良教育大附属自然環境教育センタ一紀要, 6, 7-18.

和田穣隆 - 三浦大助, 2005 , 熊野酸性火成岩類の “凝灰岩” の再検 討一大狗子半島での産状から推定される花崗斑岩マグマの定置モ 一ド. 地球惑星科学関連学会 2005 年合同大会予稿集, V056P-001.

和田穣隆・新正裕尚, 2004, 奈良県川上村中奥で見い出された複合岩 脈一苦鉄質・珪長質マグマ供給源の位置一. 地球惑星科学関連学 
会 2004 年合同大会予稿集, G017-P006

Walker. G.P.L., and Skelhorn, R.R., 1966, Some associations of acid and basic igneous rocks. Earth-Sci. Rev., 2, 93-109.

Wiebe, R.A., 1991, Commingling of contrasted magmas and generation of mafic enclaves in granitic rocks. In Didier, J. and Barbarin, B., eds., Enclaves and Granite Petrology (Developments in Petrology 13), Elsevier, Amsterdam, 393-402

大和大峯研究グループ, 1994, 紀伊山地中央部の中・古生界（その
5）一新子地域一. 地球科学, 48, 103-117.

大和大峯研究グループ, 2005, 紀伊山地中央部の中・古生界（その 9）一辻堂 - 大峯・台高・国見山地域の再検討一. 地球科学, $\mathbf{5 9}$, 287-300.

吉川敏之, 1997, 大阪東南部, 二上層群の中新世火山岩の放射年代. 地質 雑, 103, 998-1001.

Zimanowski, B., and Büttner, R., 2002, Dynamic mingling of magma and liquefied sediments. Jour. Volcanol. Geotherm. Res., 114, 37-44.

\section{（要 旨）}

和田穣隆 ·藤田千夏 - 新正裕尚, 2007 , 紀伊半島中央部, 中期中新世宮滝岩脈：火道内でのマ グマ・ミングリングとその意義. 地質雑， 113，353-365. (Wada Y., Fujita C. and Shinjoe H., 2007, The Middle Miocene Miyataki dike, central Kii Peninsula, southwest Japan : magma mingling observed in dike conduit and its implications. Jour. Geol. Soc. Japan, 113, 353-365.)

紀伊半島中央部，奈良県吉野町に露出する宮滝岩脈の形成過程を再検討した。同岩脈は 従来，多量の岩片を含むため火砕岩であると考えられてきた。今回，野外および鏡下での 観察により，宮滝岩脈は流紋岩と安山岩が互いにミングリングし，また包有物として含ま れる岩石からなることが明らかとなった。さらに花崗岩が流紋岩・安山岩に包有されると ともに，流紋岩中の花崗岩は安山岩に包有された上で包有されている．いずれの包有物と も不定形状をなし高温時に塑性変形を受けたことを示している．これらのことから，流紋 岩・安山岩両マグマは花崗岩体と岩脈定置前に一旦ミングリング・断片化した後, さらに ミングリングを続けながら上昇して宮滝岩脈を形成したと推定できる. 